\title{
Note ON THE \\ NIDIFICATION oF MANUCODIA COMRII, Sclater.
}

Comrie's Manucode.

By A. J. NoRth, F.L.S., Assistant in Ornithology.

[Plate VII.]

Manucodia comrii, Sclat., Proc. Zool. Soc., 1876, p. 459.

The Trustees of the Australian Museum have lately received from the Rev. R. H. Rickard the egg of Manucodia comrii, taken by him on Fergusson Island, off the South-East coast of New Guinea, in July, 1891. The Rev. Mr. Rickard informs me that from the 20th of June to the 20th of July he had been at various times engaged in company with his black boy shooting Manucodes on this island, but rarely saw a female. Early in July he found a nest of this species in the lower branches of a bread-fruit tree at a height of twenty-five feet from the ground. The female was on the nest, which was an open loosely made structure of vinelets and twigs placed at the extremity of the branch; having procured her, he found that she was in very indifferent plumage as though she had been sitting for a long time, and the eggs, two in number, were chipped, and just upon the point of hatching. The egg is an elongate ovoid in form, and is of a warm isabelline ground colour with purplish dots, blotches and bold longitudinal streaks, uniformally dispersed over the surface of the shell, intermingled with similar superimposed markings of purplish-grey. Length $1.65 \times 1.13$ inch.

The range of this species is confined to the islands of the D'Entrecasteaux Group. 